\title{
POR ESSA JANELA
}

Francisco Renato Lima

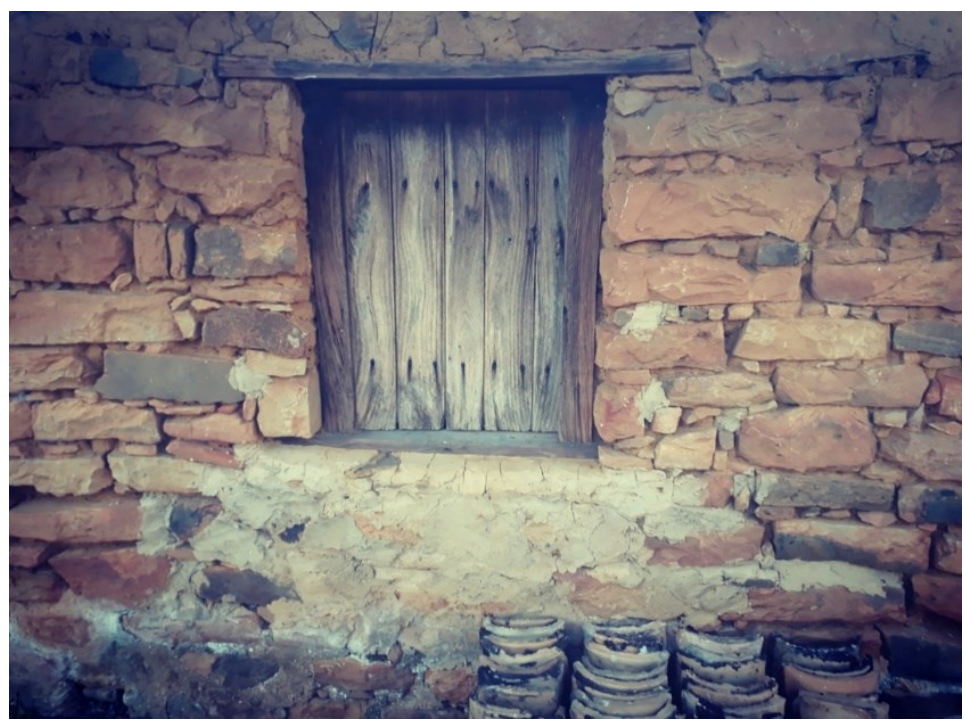

Fonte: Arquivo pessoal (LIMA, 2019)

Por essa janela, vi os primeiros e melhores nascer do sol.

Vi também, o anoitecer e os raios do trovão.

Senti os respingos da chuva.

E, por suas frestas, senti o cheiro de terra molhada.

Anunciando, lá fora, que era inverno:

o tempo da esperança renovada!

Por essa janela, vi os melhores janeiros, fevereiros até dezembro!

Por essa janela, vi melhor o mundo!

E, era nessa janela, onde gostaria de estar agora,

Debruçado, apreciando a chegada de um tempo melhor!

(17 jul. 2019, Teresina (PI)) 